\title{
Does Method of Course Delivery Matter: A Comparison of Student Performance in Hybrid, Online, and Lecture-based Introductory Sociology Courses
}

\author{
Sara Brallier, Megan McIlreavy \\ Coastal Carolina University, United States
}

\begin{abstract}
The purpose of this paper is to compare students' mastery of course content between students enrolled in three course delivery methods (hybrid, online, and traditional lecture-based) of an Introductory Sociology course. The same instructor taught a hybrid Introductory Sociology course in the spring semester of 2015, an online Introductory Sociology course in the fall semester of 2015, and a traditional lecture-based Introductory Sociology course in spring semester of 2016. Overall, there were no significant differences in student performance on, quizzes, final exam, or assignment between students in the different methods of course delivery. Final course grades did not differ by course delivery method either. The majority of students mastered course specific and general education student learning outcomes satisfactorily in all three delivery methods. Implications of these results for the design and structure of distance and hybrid courses are discussed.
\end{abstract}

\section{Introduction}

A noteworthy trend in higher education is the increased offerings of online and hybrid courses [1, $2]$. Two-thirds of all universities and colleges in the United States offer hybrid or online courses [3]. Hybrid courses incorporate blending learning in that the courses make use of both face-to-face and online learning [4]. Some academics have suggested that hybrid learning may be the best of both worlds and deliver the "optimal mix" of online and traditional learning. Hybrid courses combine the benefits of synchronous learning from a lecture-based classroom with the benefits asynchronous online learning. By meeting with students throughout the semester instructors in hybrid courses are able to informally gage learning, create collaborative learning environments, motivate students, answer questions about course requirements, and engage in spontaneous an unstructured discussion with students. The addition of an asynchronous online component offers the capacity for instructors to offer independent, flexible, convenient, accessible studentcentered learning, an improved ability to analyze and assess learning and provide immediate feedback on quizzes and exams, the opportunity for participation in discussion by students who are uncomfortable participating in the public setting of the classroom, and consistent access for students to course materials [1], [4], [5], [6], [7], [8]. Moreover, in hybrid courses a considerable amount of "course housekeeping" can be done online. This allows the instructor to make more effective use of class time. By holding online office hours, posting notes and handouts for students who missed a class, providing feedback and posting grades online, the instructor can reduce the amount of time spent in class returning papers and answering questions about assignments, course structure, and grading procedures [9], [10].

Despite the growing notion that hybrid instruction may be the "best of both worlds," there has been relatively little research comparing mastery of student learning outcomes between hybrid courses and completely online or lecture based courses [1], [2], [4]. To date, research of the effectiveness of hybrid instruction compared to online or lecture based instruction has yielded mixed results. Both Lack [11] and Means and colleagues [12] conducted a meta-analyses of research comparing online, traditional and hybrid courses. Their findings support the 'optimal mix' assertion, in that students who completed hybrid courses performed significantly better than students enrolled in lecture-based courses. However, Wu's [2] conclusion from a meta-analysis of the literature suggests that online or hybrid courses do not produce significantly different results in student learning compared to lecture-based learning. The purpose of this study is to compare student learning outcomes in a hybrid Introductory Sociology course to student learning outcomes in online and traditional lecture-based versions of the same course.

\section{Methods}

\subsection{Course Design}

This study was conducted within an Introductory Sociology course, which is required of all Sociology majors and can be used by students from other majors to fulfill a general education requirement at a four-year public university in the southeastern United States. This course provides students with an introduction to the sociological study of social interaction, social structures, social institutions, 
social inequalities, social change, the social construction of human life, and other selected topics. The course also demonstrates how sociology draws upon a variety of social scientific research methods, sociological concepts and social theory to reveal the social basis of everyday life by exploring the interplay between society and the individual. The course objectives for this course were as follows: (1) Demonstrate an understanding of sociology's basic concepts, theoretical frameworks, and research processes, (2) Demonstrate the ability to apply the sociological perspective or imagination to understand human behavior within its social context, (3) Gain insight into the core sociological concepts of social groups and social control, social inequality, and social institutions, (4) Demonstrate knowledge of methods social scientists use to conduct research, (5) Illustrate and communicate key sociological concepts and their interrelations, (6) Explain the substance and centrality of sociology theory as it relates to the science and application of sociology, and (7) Demonstrate an understanding of how class, status, race, ethnicity, gender and/or sexuality steer the individual life processes. The general education student learning outcomes for this course were: (1) Demonstrate a basic knowledge and understanding of human health or behavior and (2) Demonstrate a basic knowledge and understanding of human behavior in societies.

\subsection{Participants}

The participants in this study were the 93 students enrolled in Introductory Sociology during the spring and fall semesters of 2015 and the spring semester of 2015. Thirty-seven students were enrolled in the hybrid form of the class, 24 were enrolled in the online version, and 32 were enrolled in the lecture-based form. The sample consisted of 57 women and 36 men. The mean age of the students was 20.31 years $(S D=3.29)$. The racial distribution consisted of 53 Caucasians and 40 Non-Caucasian students. The class rank distribution contained 26 freshmen, 35 sophomores, 20 juniors, 7 seniors, and 5 non-degree seeking students

\subsection{Materials}

Course materials were consistent across all versions of the classes over the three semesters of the study. In each class the same book, course assignments, discussions, and quizzes and exams were used. The text assigned for all versions of the course was Henslin's [13] Sociology: A down-toearth approach. The university's Institutional Research Office provided student demographic and academic data in accordance with the university's privacy policies.

\subsection{Procedures}

The same instructor (one of the co-authors) taught a hybrid Introductory Sociology in the spring semester of 2015, a $100 \%$ online section of the course in the Fall of 2015, and a $100 \%$ in-class version of the class in the spring semester of 2016. Although students in the lecture-based course had access to some online elements (e-mail, online assessments, and distribution of course materials, such as PowerPoints), the majority of course content was delivered using traditional teaching methods such as lecture and in-class discussions and activities. Course materials and assessments were kept consistent across semesters and course delivery methods. The hybrid course was taught using the replacement model of hybrid teaching [4]; (in that one class per week was held in the classroom, the other class was redirected to online activities). Students in the hybrid course attended 75 minutes of lecture/class activities a week for the 16-week semester. Students in the lecture version attended two classes a week for a total of 150 minutes of lecture/activities a week for the 16-week semester. In all three versions of the courses quizzes and exams were taken online. Assignments were submitted online, and students were able to contact the instructor, access course materials, and their grades through Moodle, the course management system. In the online and hybrid version of the course students were asked to view and respond to additional materials (videos, outside webpages, and short readings) in an asynchronous online discussion forum.

\section{Results}

Preliminary analyses were conducted to assess if students who completed the hybrid courses $(n=37)$ differed from students who completed the online $(n=24)$ and lecture-based formats $(n=32)$ in regards to their academic and demographic characteristics. Using cumulative grade point average (GPA) as a measure of academic achievement, the one-way between-groups analysis of variance indicated that there was no significant difference in the mean GPAs among students in the hybrid course $(\mathrm{M}=3.07$. $S D=.65)$, online $(\mathrm{M}=2.80, S D=.86)$, or lecture-based $(\mathrm{M}=3.05, S D=.87)$ versions of the course $[\mathrm{F}=.945$ ( $\mathrm{df}=2,81), \mathrm{p}=.393$ ]. The students in the hybrid course did not differ significantly from the students in the other two versions in terms of age $[\mathrm{F}=1.948$ ( $\mathrm{df}=2,90), \mathrm{p}=.146]$. Additionally, chi-square tests for independence revealed no significant relationship between course type and the demographic variables of gender, class rank, nor race (See Table 1). 
Table 1. Relationship between Course Delivery Methods and Demographic Variables of Gender, Class Rank, and Race

\begin{tabular}{|l|l|l|l|l|l|l|l|l|}
\hline & \multicolumn{7}{|l|}{ Course Delivery Method } & \multicolumn{2}{l|}{} \\
\hline & \multicolumn{2}{|l|}{$\begin{array}{l}\text { Hybrid } \\
\text { Course }\end{array}$} & $\begin{array}{l}\text { Lecture } \\
\text {-based } \\
\text { Course }\end{array}$ & \multicolumn{2}{l}{$\begin{array}{l}\text { Online } \\
\text { Course }\end{array}$} & & \\
\hline Variable & $\mathrm{N}$ & $\%$ & $\mathrm{~N}$ & $\%$ & $\mathrm{~N}$ & $\%^{2}$ & $X^{2}$ & $\mathrm{p}$ \\
\hline Gender & & & & & & & & \\
\hline Female & 21 & 57 & 19 & 59 & 17 & 71 & 1.29 & .254 \\
\hline Male & 13 & 43 & 13 & 41 & 7 & 29 & & \\
\hline Class Rank & & & & & & & & \\
\hline Senior & 1 & 3 & 4 & 13 & 2 & 8 & 8.90 & .179 \\
\hline Junior & 5 & 15 & 7 & 22 & 8 & 33 & & \\
\hline Sophomore & 18 & 55 & 8 & 26 & 9 & 38 & & \\
\hline Freshman & 9 & 27 & 12 & 39 & 5 & 21 & & \\
\hline Race & & & & & & & & \\
\hline Caucasian & 18 & 49 & 20 & 63 & 15 & 63 & 6.60 & .578 \\
\hline $\begin{array}{c}\text { Non- } \\
\text { Caucasian }\end{array}$ & 19 & 51 & 12 & 37 & 9 & 37 & & \\
\hline
\end{tabular}

Students in all three delivery methods were administered the same 14 multiple-choice chapter quizzes. Each quiz was worth 20 points. A quiz score was calculated by computing the total number of points earned on the 14 quizzes and dividing by the 280 possible points. The quizzes were designed to measure mastery of course specific student learning outcomes. The one-way between-groups analysis of variance was conducted to explore the impact of course delivery method on students' quiz score. There was no statistically significant difference at the $\mathrm{p}<.05$ level in the quiz score for course delivery method (See Table 2).

Students in all three delivery methods were asked to complete the same 50-point multiple choice final exam. This exam was designed to measure the mastery of general education learning outcomes. The one-way between-groups analysis of variance was conducted to explore the impact of course delivery method on students' final exam score. There was no statistically significant difference at the $\mathrm{p}<.05$ level in the final exam score for course delivery method (See Table 2). The quizzes and final exam for this course focused on more basic levels learning (remembering, understanding, and applying).

In all three delivery methods students were asked to submit four written assignments in which they were asked to use a sociological theories and/or constructs to analyze data. Each paper was worth 100 points. An assignment score was calculated by computing the total number of points earned on the four assignments and dividing the total by the 400 possible points. The student learning outcomes for the four papers measured more advanced levels of learning (analyzing and evaluating). The one-way between-groups analysis of variance was conducted to explore the impact of course delivery method on students' mean assignment score. There was no statistically significant difference at the $\mathrm{p}<.05$ level in the assignment score for course delivery method (See Table 2).

A final analysis was conducted to examine the relationship between course delivery method and course grade distribution. Numeric averages were converted the letter grades to grade points $(A=4$, $\mathrm{B}+=3.5, \mathrm{~B}=3, \mathrm{C}+2.5 ; \mathrm{C}=2 ; \mathrm{D}+=1.5 ; \mathrm{D}=1 ; \mathrm{F}=0) . \mathrm{A}$ one-way analysis of variance revealed no significant relationship between course delivery mode and course grades (See Table 2).

Table 2. Relationship between Course Delivery Methods and Course Performance

\begin{tabular}{|l|l|l|l|l|l|l|}
\hline & \multicolumn{3}{|l|}{ Course Delivery Method } & & \\
\hline & $\begin{array}{l}\text { Hybrid } \\
\text { Course }\end{array}$ & $\begin{array}{l}\text { Lecture } \\
\text {-based } \\
\text { Course }\end{array}$ & $\begin{array}{l}\text { Online } \\
\text { Course }\end{array}$ & & & \\
\hline & $\begin{array}{l}\mathrm{M} \\
(S D)\end{array}$ & $\begin{array}{l}\mathrm{M} \\
(S D)\end{array}$ & $\begin{array}{l}\mathrm{M} \\
(S D)\end{array}$ & $F$ & $\mathrm{df}$ & $\mathrm{P}$ \\
\hline Quiz & 86.5 & $\begin{array}{l}83.6 \\
(16.0)\end{array}$ & $\begin{array}{l}87.7 \\
(8.0)\end{array}$ & 1.26 & 2,90 & .362 \\
\hline $\begin{array}{l}\text { Final } \\
\text { exam }\end{array}$ & $88.3)$ & $\begin{array}{l}84.1 \\
(9.5)\end{array}$ & $\begin{array}{l}85.5 \\
(19.2)\end{array}$ & 1.25 & 2,90 & .289 \\
\hline $\begin{array}{l}\text { Assign- } \\
\text { ments }\end{array}$ & 84.7 & $\begin{array}{l}91.9 \\
(17.9)\end{array}$ & $\begin{array}{l}86.9 \\
(13.1)\end{array}$ & 1.02 & 2,90 & .369 \\
\hline $\begin{array}{l}\text { Course } \\
\text { grade }\end{array}$ & 3.4 & $\begin{array}{l}3.5 \\
(0.7)\end{array}$ & $\begin{array}{l}3.2 \\
(1.8)\end{array}$ & 0.70 & 2,90 & .480 \\
\hline
\end{tabular}

\section{Discussion}

Consistent with previous research, the data from this study suggests that students do as well in completely online classes as they do when they attend lecture [2]. Based on the literature, we anticipated that students in the hybrid course would perform better compared to students in the online course or traditional lecture-based courses; the data did not support this. Student performance on all components of the course did not differ by course delivery method.

In both the online and hybrid versions of the course students were asked to complete weekly discussion postings responding to questions based on content-driven online materials such as TED Talks, video links from the library, academic web-sites, and short articles. Our findings indicate the use of online discussion instead of the face-to-face discussion used in the lecture-based course did not negatively (or positively, for that matter) affect student mastery of the course specific or general education learning outcomes.

Moreover, our analyses suggest that students who enrolled in the online and hybrid courses were similar to students who enrolled in the online and traditional lecture based course in terms of academic (cumulative gpa) and demographic variables (gender, class rank and race) and that these variables did not differentially predict course performance by course delivery methods. 
The administration at the university at which this study was conducted had expressed concern about offering a first-year general education course online. Their concerns are based on the assumption that first-year students need the full 150 minutes of weekly contact with the instructor in order to motivate them and provide face-to-face feedback and direction. Our research suggests that their concerns are unfounded as mastery of neither course specific or general education student learning outcomes differed by course type or class rank. Moreover, the majority students in all delivery modes successfully demonstrated mastery of both lower (remembering, understanding, and applying) and higher levels of learning (analyzing and evaluating).

Successful online and hybrid instruction is dependent upon the development of the course using best-practices and the preparedness of the instructor of offer online education [14]. Some of the potential problems of offering an Introductory Sociology course online may have been offset by the use of best practices for online/hybrid instruction. The instructor received training and the course was reviewed by an expert in online education to ensure that the course was clearly designed and laid-out, easy to navigate and use, organized around strong pedagogical standards, and made use of the most current and relevant instructional materials available. At the beginning of the semester students in the online course were sent an email communicating the technological capacities and skill required for the course as well as strategies for effective online learning.

Effective online instruction incorporates substantial interaction between the instructor and students and between students [15] Interaction between the students and instructor in the online Introductory Sociology course was facilitated by frequent online announcements and emails regarding course expectations, assignment instructions and due-date. The instructor provided detailed feedback and encouragement in response to student assignments submitted online.

As Brewer and Brewer [14] assert, the goal of online instruction is not to duplicate the face-to-face classroom; but instead to provide a successful educational experience. Our findings support Russell's [16] phenomenon of "no significant difference" when comparing different course delivery methods using online instruction. The findings from this study suggest that when online course delivery methods are properly and effectively used, it does not affect student learning. The student mastery of learning outcomes is independent of the course delivery method and instead is dependent on the pedagogical practices used in the course.

\section{References}

[1] H.W. Webb, G. Gill, and G. Poe, "Teaching with the Case Method Online: Pure versus Hybrid Approaches", Decision Sciences Journal of Innovative Education, WileyBlackwell, Malden MA, 2005, pp. 223-250.

[2] W. Wu, Y.J. Wu, C, Chen, H. Kao, C., and S. Huang, "Review of Trends from Mobile Learning Studies: A Meta-analysis", Computers \& Education, Elsevier, London, 2012, pp. 817-827.

[3] B. Parsad and L. Lewis, Distance Education as Degree-Granting Post-Secondary Institutions: 2006-2007. Washington, DC: U.S. Department of Education, 2008.

[4] C.J. Auster, "Blended Learning as a Potentially Winning Combination in Face-to-face and Online Learning", Teaching Sociology, Sage Publications, Thousand Oaks, CA. 2016, pp. 39-48.

[5] G. Black, "A Comparison of Traditional, Online, and Hybrid Methods of Course Delivery", Journal of Business Administration Online, Arkansas Tech University School of Business, Russellville, AR, 2002, pp. 1-9.

[6] J.M. Graham, L.A. Mogel, S.A. Brallier, and L.J. Palm, "Do You Online?: The Advantages and Disadvantages of Online Education", Bridges, Coastal Carolina University, Conway, SC, 2008, pp. 27-36.

[7] M. Matelski, “'Online 'Connections': Teaching Family Communication as a Hybrid Course. The International Journal of Learning, Common Ground Publishing, Champaign, IL, 2010, pp. 57-65.

[8] University of Washington. (2012). Leading Change in Public Higher Education: A Provost Report Series on Trends and Issues Facing Higher Education. http://www.washington.edu/provost/files/2012/11/edtrends (12 May 2016)

[9] M. Tang, and R. Byrne, "Regular Versus Online Versus Blended: A Quantitative Description of the Advantages of the Electronic Modes and a Quantitative Evaluation", International Journal of E-Learning, The Association for the Advancement of Computing in Education, Waynesville, NC, 2007, pp. 257-266.

[10] J. Wong, "Traditional Versus Hybrid Courses: A Comparative Analysis", The International Journal of Learning, Common Ground Publishing, Champaign, IL, 2006, pp.163-170.

[11] K. Lack, Current Status of Research on Online Learning in Postsecondary Education, New York, New York, Ithaca S+R, 2013.

[12] B. Means, Y. Toyama, R. Murphy, M. Bakia, and K. Jones, Evaluation of Evidence Based Practices in Online Learning: A Meta-Analysis and Review of Online Learning Studies, Washington, DC: U.S. Department of Education, 2009. 
[13] J. Henslin, J., Sociology, A Down-to-Earth Approach. Boston: Allyn and Bacon, 2012.

[14] P.E. Brewer, and E.C. Brewer, "Pedagogical Perspectives for the Online Education Skeptic", Journal on Excellence in College Education, Miami University, Oxford, OH, pp.29-52, 2015.

[15] M. Clark-Ibanez and L. Scott, "Learning to Teach Online", Teaching Sociology, Sage Publications, Thousand Oaks, CA, 2008.

[16] T.L. Russell, The No Significance Difference Phenomenon. Chapel Hill, NC: Office if Instructional Communications, University of Chapel Hill, NC, 1999. 